\title{
Chicken Cells
}

National Cancer Institute

\section{Source}

National Cancer Institute. Chicken Cells. NCI Thesaurus. Code C18695.

Cells derived from the chicken used as a biological model for research. 